\title{
Education Reform and the Normalisation of Private Education in Slovenia
}

MARJAN ŠIMENC ${ }^{1}$

$\approx$ This article examines the long-term effects of the regulation of private education adopted in the course of the education reform in 1996 and the sustainability of the guiding principles that served as the starting point for this regulation. It reviews the guiding principles of the introduction of private education, the goals of the reform laid down in the White Paper in 1995 and the regulations introduced on the basis of these tenets. It follows up on the 'life' of the legal solutions and the history of (attempted) amendments of the legislation, which generally start in the Slovenian Parliament and then proceed all the way to the Constitutional Court. The article also examines the effects of the adopted regulation: how the private education sector has established itself and what kind of relationship it has developed vis-a-vis public education. The second part of the article explores certain developments in the field of education in Slovenia and on the global scale, using them as the basis for assessing the sustainability of the goals that guided the education reform. The thesis proposed by the article is that it is the normalisation of private education in Slovenia should be considered the main achievement of the education reform.

Keywords: education reform, private education, human rights, normalisation 


\section{Šolska reforma in normalizacija zasebnega šolstva v Sloveniji}

MARJAN ŠIMENC

$\approx$ Članek obravnava dolgoročne učinke urejanja položaja zasebnega šolstva v šolski reformi iz leta 1996 in »trajnost « načelnih izhodišč, iz katerih se je izhajalo. Prikaže načelna izhodišča uvajanja zasebnega šolstva, cilje sprememb, kot so opredeljeni v Beli knjigi leta 1995, in zakonsko ureditev, ki je bila vpeljana na osnovi načelnih izhodišč. Spremlja »življenje« zakonskih rešitev in zgodovino (poskusov) sprememb zakonodaje. Zakonodajo se najprej poskuša spremeniti v parlamentu, potem pa se politika spreminjanja nadaljuje na ustavnem sodišču. Članek opisuje tudi »učinkovanje « zakonodajnih rešitev: kako se oblikuje sektor zasebnih šol in kak odnos se razvije med javnim in zasebnim šolstvom. V drugem delu članek obravnava nekatere globalne procese na področju edukacije in na tej osnovi ocenjuje »trajnostnost « ciljev, iz katerih je reforma izhajala. Teza članka je, da je glavni dosežek reforme normalizacija zasebnega šolstva v Sloveniji.

Ključne besede: šolska reforma, zasebno šolstvo, človekove pravice, normalizacija 


\section{Introduction}

One of the prominent elements of the education reform that ensued from the White Paper (1995) and the adoption of new legislation in 1996 was the introduction of private schools. At the time, the situation appeared to be unprecedented, since reforms generally build on what is already in existence rather than introducing something completely new; however, the legislation in education applicable prior to the reform did not provide for private education. This change gave rise to much uncertainty, since it was not very clear how the structural changes and the introduction of a new element would affect other elements and the field of education as a whole.

The reform can be evaluated from various aspects; with twenty-five years of hindsight, two considerations can be put centre stage. The first relates to the long-term effects and the stability of the legislative solutions introduced in the course of the reform, including a review of the achievement of the objectives pursued by the reform. The second refers to the sustainability of the guiding principles that served as the starting point for the introduction of changes. The education reform was designed in specific social circumstances as a response to issues relevant at the time. A quarter of a century later, global developments are marked by new trends, so it makes sense to examine whether the principles that guided the regulation of private education are still valid.

\section{Education reform in Slovenia in 1996}

Before 1991 (i.e., prior to Slovenia's declaration of independence), private schools did not exist in Slovenia. The new education legislation that came into force in 1996 introduced private schools into the education system. However, from a historical point of view, private education had been present in the territory of Slovenia. At the time of the Habsburg Monarchy, private schools were in existence, but they were few in number and not financed by the state. After the First World War and the establishment of the Kingdom of Serbs, Croats and Slovenes, the new state adopted an even less favourable approach to private schools, so their number soon dropped even further; after the Second World War, private schools were prohibited (Šimenc, 1996).

It may seem as if the education reform put Slovenia in an extraordinary position, since the introduction of private schools could start from scratch without being limited by an established tradition of private education. However, this was not the case. At the time of independence in 1991, two religious secondary schools providing education for clergymen were already operated by 
the Roman Catholic Church, but the education provided was not formally recognised. Furthermore, the Waldorf elementary school was founded in 1992, so education had already undergone some internal differentiation before the education reform. The new legislation adopted in 1996, therefore, only introduced private schools de iure, while they had de facto already existed. Private schools had also been partly integrated into the education system: certificates issued by these schools were officially recognised; private schools were also awarded public funding on the basis of concessions. Nevertheless, these were only partial and makeshift solutions. The education reform in 1996 included private schooling in the education legislation, thereby providing private education with a regulatory framework at a system level (Krek \& Šimenc, 1996).

The goals pursued in the regulation of private schools in 1996 were defined in the White Paper on Education in the Republic of Slovenia as follows:

The goal for regulating the status of private schools is a legal situation whose requirements for the establishment of private schools and the principles of their operation will be fully transparent. The legal situation of private education should be in agreement with the stipulations of international declarations and conventions signed by Slovenia. The relation between the public and the private sector should enable private schools to enrich the public offerings, enable parents to choose the type of education they wish for their children, contribute to a better adaptability of the public system, and complete the public school network (but not limit or destroy it). Mechanisms for the quality control of private schools are needed; at least, in the areas where they are replacing the public school system. The private school sector must be clear and transparent enough so that parents, in deciding on a certain private school, know what they have chosen and do not send the children to schools whose quality and educational orientation are not completely known. Substitutional private schools should be accessible to all classes of [the] population. (Krek, 1996, pp. 238-239)

The quote refers to the key goals of the regulation of private education. A crucial element of the mission of private school regulation is mentioned in the second paragraph: international conventions required Slovenia to change its legislation so as to enable parents to choose the appropriate education for their children, also providing the choice of private schools. There is no doubt that international declarations and conventions oblige the state to facilitate the establishment and operation of private schools. Moreover, the goals listed above also refer to two significant aspects of the approach to private education: on the 
one hand, the establishment of private schools must be facilitated, yet on the other hand, private education must be regulated to ensure that private schools do not jeopardise the public school network.

Since these goals are very general in nature, it is useful to verify to what extent the adopted legislation actually provided for the implementation of these goals. The legislation adopted in 1996 was based on the conceptual design of private education defined in the White Paper. Several provisions refer to private schools, particularly the Organisation and Financing of Education Act (Law, 1996), but only the most pertinent will be discussed in detail below.

Article 17 of the Organisation and Financing of Education Act (Law, 1996) defines the adoption process for curricula of private schools that provide officially recognised education and contains the requirement of 'an equivalent education standard of private schools' (Ibid., p. 40). ${ }^{2}$ The benchmark for the assessment of the education standard of private schools is public school curricula. Article 86 stipulates the conditions that must be met by private schools for them to be eligible for public co-funding. The co-funding rate is determined as a ratio of the funding allocated to public schools, granting private schools (elementary and secondary) $85 \%$ of the funds allocated to public schools for their day-to-day operation. The aim of the co-financing of private schools was to ensure an appropriate quality of education for children in private schools but also to avoid private schools becoming a privilege of the children of the wealthiest parents. Public funding of private schools allows tuition fees to remain relatively low. Article 87 refers to limitations of public co-funding for private schools in case 'the existence of the sole public school in the same school district is jeopardised' (Ibid, p. 148). If a public elementary school is threatened by the existence of a private school, the funding of the private school is discontinued. Article 88 limits the tuition fees charged by private schools to $15 \%$ of the amount allocated to public schools per student. Not only does public co-financing allow for affordable tuition fees, making sure that access to private schools is not limited to the elite; public funding also involves clear conditionality: to receive public funding, private schools must agree to limited tuition fees. Article 89 links the remuneration of professional staff in publicly co-funded private schools to remuneration levels in public education. This is another provision aimed at protecting public education: private schools receiving public funding cannot use higher salaries as a means to attract the best teachers from public schools, thereby undermining public education.

2 For schools using alternative pedagogical approaches (Steiner, Montessori, etc.), this requirement is more relaxed: the act only requires them to provide 'the minimum knowledge that allows for a successful completion of schooling. (Law, 1996, p. 40). 
These provisions demonstrate how the goals and principles defined in the White Paper were translated into legislation. The private domain is defined in relation to the public domain. Private school curricula must ensure an appropriate quality of education. Public co-funding is available but subject to clear conditionality, with all regulations serving the same purpose: making sure that the existence of private school does not undermine the quality of education and making private schools accessible to everyone.

\section{Further development of the regulatory framework of private education}

The regulation of private education adopted in 1996 paved the way for various attempts to regulate the relationship between the public and private domain, some even running contrary to the initial arrangement. In fact, the government in power between 2004 and 2008 placed a strong emphasis on competition and the private sector. In 2007 , the government submitted a bill to parliament, aiming to amend the relevant legislation along the same lines. The document contained several reasons explaining why legislative changes were required, also referring to changes related to private education. Explaining the aim of the changes to be introduced, the document referred to the White Paper, claiming that 'The Amending Act is in line with the principles and goals of the White Paper from 1996' (Ministry, 2007, p. 8).

One of the key proposed amendments was equalising the public funding for private and public schools. This would mean that private schools would no longer receive $85 \%$ of the funds allocated to public schools but would be granted the same amount. The rationale behind this proposal made reference to the small number of private schools: 'In the school year 2005/2006, 0.8 per cent of pupils and students were enrolled in private elementary and secondary schools (o.12 per cent in elementary schools and 2.02 per cent in secondary schools)' (Ministry, 2007, p. 8).

This meant that the aim of the regulatory framework was no longer ensuring the quality of private education and protecting the public school network as enshrined in the White Paper; the new mission was to compete with Europe in terms of the quantity of private schools. The proposed amending act established a ranking of countries in terms of the number of children enrolled in private schools and proceeded on the basis that Slovenia's goal should be to improve its ranking. The government document first made reference to the White Paper, but then introduced a goal based on the premise that the higher the number of private schools, the greater the benefit for the country. This goal 
is not compatible with the principles and goals of the White Paper. This shows that the White Paper left such a powerful impression on the debate on education in Slovenia that politicians referenced it even when proposing measures contrary to the Paper itself.

The attempts to amend the education legislation in 2007 were only partially successful. The reason for their failure was protests: the teachers' trade union (SVIZ) presented the National Assembly with a call for action, 'For highquality public education' signed by over 71,000 individuals who opposed the increase of public funding awarded to private schools to the same level as that awarded to public schools. (Protner, 2010, p. 57) Because the legislative procedure failed, several deputies lodged an appeal before the Constitutional Court, claiming that the inequality in the public co-funding of public and private education was unconstitutional. The court rejected the appeal for procedural reasons. A similar appeal was then lodged by parents whose children were enrolled in a private primary school. The Constitutional Court ruled in 2015 that the inequality in the public co-funding of public and private primary schools was contrary to the Constitution. The ruling was unexpected since the court had already ruled on the matter in 2001, upholding the concepts enshrined in the White Paper. ${ }^{3}$ The key argument put forward by the Constitutional Court was the following:

In contemporary democratic societies, the mandatory aspect of education (i.e. mandatory elementary education) is interpreted in a narrow manner as referring only to the content of the statutory curricula rather than as also referring to the educational establishments providing these curricula. Paragraph 2 of Article 57 of the Constitution (which stipulates that "primary education is compulsory and shall be financed from public funds") therefore guarantees children the right to participate in mandatory officially recognized primary education free of charge, regardless of whether this education is provided by a public or private establishment. (Constitutional Court, 2014, par. 20)

The Constitutional Court did not refer to any specific source to substantiate its claim that what mattered in contemporary democratic societies was the content of education and not whether this education is provided by private or public schools. However, this claim, deemed by the Slovene Constitutional Court as self-evident and requiring no justification, could well give free rein to the extensive privatisation of education (Šimenc, 2016).

3 Some commentators feel that it needs to be pointed out that the position of the Constitutional Court on the funding of private education in 2001 was adopted when the matter at issue before the Court was not the funding of private schools but rather an article of the Organisation and Financing of Education Act referring to confessional activities in public schools. (Rifel, 2016) 
It can be concluded from the above that the manner in which the relationship between public and private schools was conceived in the White Paper was so convincing for Slovene society that it took a ruling of the Constitutional Court for this arrangement to be changed. The ruling of the court requiring the equalisation of the funding of private and public elementary schools was perceived by the public as contentious; the parliament also failed to adopt the necessary legislative amendments to implement it. As a result, a second dispute challenging the constitutionality of the legislation on the financing of private schools was launched. In 2020, the Constitutional Court again ruled that elementary education must be free of charge for private school students; however, it limited this requirement to mandatory curricula. Since public schools also receive public funding for non-mandatory curricula, this ruling of the Constitutional Court maintained the differentiation between the public funding of public and private schools.

\section{Changes in education in the post-White Paper period: global developments}

The period after the adoption of the White Paper was marked by the encroachment of neoliberal ideas into the field of education. Economic globalisation has gradually diminished the importance and influence of nation-states and has contributed to the development of 'market-based reforms and hence characterized the essence of globalization of education: decentralization, privatization, and increasing efficiency of education' (Sahlberg, 2004, p. 68). The creation of a global education industry (Verger et al., 2016) is fostered by transnational institutions, such as the World Bank, and transnational corporations that promote the privatisation and standardisation of education at the global level; the effects of this are most evident in parts of Latin America, Africa and Asia where public education systems neglected by economically weak countries have gradually become commercialised and privatised.

At the international level, these trends evoked many responses. Reports of the Special Rapporteur on the right to education point out that the right to education is jeopardised in periods of quick proliferation of private schools and underscore the responsibility of states for the exercise of the right to education and the need to ensure that education remains a public good. (Special Rapporteur, 2014, 2015). In the 2019 report, the Special Rapporteur informs the Human Rights Council and States Members of the United Nations about the newly adopted Abidjan Principles and recommends their full implementation (Special Rapporteur, 2019). 
The Abidjan Principles, bearing the full title The Abidjan Principles on the human rights obligations of States to provide public education and to regulate private involvement in education, represent the most comprehensive response to global privatisation trends in education. This complex document is meant to provide guidance to governments facing these new developments. ${ }^{4}$

The point of departure for the text is the importance of the right to education which is under threat in many places due to the growing privatisation and commercialisation of education, giving private interests and profit-making free reign. This is why the principles highlight the role of states and their obligations to provide for the exercise of the right to education. According to the Principles, this obligation is closely related to the provision of free public education. The second overarching principle thus reads as follows: 'States must provide free, public education of the highest attainable quality to everyone within their jurisdiction as effectively and expeditiously as possible, to the maximum of their available resources', and the fifth overarching principle explicitly states: 'States must prioritise the funding and provision of free, quality, public education [...]'(Abidjan Principles, 2019, p. 7)

The Abidjan Principles underscore that states should realise the right to education by prioritising a free, quality, public education system accessible to everyone and that the respect of all requirements arising from human rights is a prerequisite for the co-funding of private schools. All of the above clearly indicates that global developments have shifted the focus towards certain aspects of the right to education that had previously not attracted much attention. The responsibility of states to realise the right to education has gained significance, and potential negative effects of the privatisation of education have been recognised. The Abidjan Principles may be a document of weaker authority compared to the generally recognised international acts on human rights; however, similar changes in focus can also be seen in the interpretation of those documents. The fact that no modern state can simply withdraw from the education sector and leave all responsibility for education to private actors has also been highlighted in rulings of the International Court for Human Rights. The ruling in the case of Louise O'Keeffe is a particularly relevant case in point.

In 1973, Louise O'Keeffe was a student at a national school when she was sexually assaulted by her teacher Leo Hickey. The abuse she had suffered led O'Keeffe to bring proceedings against both Hickey, as well as the state. Her action against the Republic of Ireland was dismissed in Ireland, citing the type of

4 The document was adopted in February 2019 as a result of three years of consultations involving independent experts around the globe, with a group of international NGOs acting as the main driver of the drafting of the Principles. 
school she had attended as the key argument for the dismissal. National schools are schools that are merely funded but not managed by the state, since these are private schools with denominational management. Because the school was not managed by the state and the teacher Leo Hickey was not a civil servant, Irish courts ruled that the state could not be held responsible for any abuse taking place in these schools. The applicant, therefore, turned to the European Court of Human Rights which ruled in 2014 that the state was responsible for the violation of Article 3 of the Convention for the protection of human rights and fundamental freedoms.

Commentators highlight the significance of the ruling for understanding the obligations of the state when it comes to the protection of rights, especially in the field of education. Several points made on the grounds of the delivered judgement are of particular relevance.

Moreover, the primary education context of the present case defines to a large extent the nature and importance of this obligation. The Court's case-law makes it clear that the positive obligation of protection assumes particular importance in the context of the provision of an important public service such as primary education, school authorities being obliged to protect the health and well-being of pupils and, in particular, of young children who are especially vulnerable and are under the exclusive control of these authorities (ECtHR, 2014a, par. 145).

Due to the nature of this obligation, the state cannot simply evade the duty of protecting a child simply because the child attended a private school. The grounds of the judgement thus place a particular emphasis on the obligation of the state and the fact that the abuse occurred in a primary school that is deemed 'an important public service. The ruling gives particular consideration to the obligation of the state: 'It is an inherent obligation of government to ensure their protection from ill treatment, especially in a primary education context, through the adoption, as necessary, of special measures and safeguards' (ECtHR, 2014a, par. 146).

According to the analysis of Renáta Uitz, the French version of the ruling clearly shows that the obligation of the state does not relate to a particular right arising from a particular article of the convention; as put by the court, it is in the very nature of the government's tasks in public primary education. In the words of the French version "les pouvoirs publics ont l'obligation, inhérente à leur mission, de protéger [...]" [para 146, emphasis added], which translates literally as "public authorities have an obligation, inherent in their mission, to protect [...]"” (Uitz, 2014). 
The ruling of the court thus emphasises two things: firstly, that primary education constitutes an important public service; second, that the state therefore has a positive obligation to protect children in primary schools. The ruling is accompanied by a dissenting opinion of five judges, which is yet another indicator of the significance of the O'Keeffe ruling for the regulation of the relationship between the state and private education. This opinion highlights some additional points in the ruling:

A democratic society may flourish only in a State that respects the principle of subsidiarity and allows the different social actors to self-regulate their activities. This applies also to the domain of education. Legislation pertaining to private education should respect the legitimate autonomy of private schools. Article 2 of Protocol No. 1 guarantees the right of parents to ensure education and teaching in conformity with their own religious and philosophical convictions. It is clear that the democratic State has to respect the education choices of the parents as well as the parents' primary responsibility for the development and well-being of their children (ECtHR, 2014b, par. 7).

The dissenting judges are also critical of the court's ruling: 'We regret to note that the Court, established to ensure the protection of human rights and fundamental freedoms, promotes as a remedy for rights violations a model of the State which restricts the scope of freedom and individual responsibility' (ECtHR, 2014b, par. 20).

What the judges point out in the dissenting opinion is that the ruling constitutes an extension of the state's obligations. In their opinion, private schools have the autonomy and the right to regulate their activities themselves, which would mean that interventions and the regulation of private education by the state should be limited. However, the result of the ruling is that the state's obligations and its competences in this area are being extended in the name of the protection of children's rights. This means that the state is obliged to regulate the operation of schools, including private schools in greater detail, so as to adequately protect the rights of children. The dissenting opinion also stresses that judges were not unanimous and that a small group of judges opposes the court's ruling.

Furthermore, the ruling represents a shift in the interpretation of international acts on human rights. Commentators of the ruling note that its longterm effects are not yet entirely clear; however, it is clear what direction they will take. The court's ruling indicates that the state has a vital role in the field of education and that this role obliges it to not leave the responsibility for this 
field to others. The interpretation of human rights is not oriented towards the withdrawal of the state from education but rather towards states being more involved in this area.

\section{Achievement of the objectives of the reform}

The reform can be assessed based on its own benchmarks, specifically in terms of the implementation of the goals it had set for itself. Such evaluations have already been undertaken (Globokar, 2011; Šimenc, 2003) and have concluded that the objectives of the reform have largely been fulfilled. A 'legal situation whose requirements for the establishment of private schools and the principles of their operation will be fully transparent' (Krek, 1996, p. 238) has been established, which is fully in line with the first objective of the White Paper. Parents have been given the possibility to opt for private schools, 'mechanisms for the quality control of private schools' (Krek, 1996, p. 239) are in place, public co-funding allows for lower tuition fees, making sure that private schools do not become elite institutions. The results of secondary school leaving examinations prove that private secondary schools provide high quality education (Globokar, 2011; Šimenc, 2003). Researchers have not detected any indication of private education fostering the establishment of elite private schools (Flere \& Klanjšek, 2011). When it comes to general upper secondary schools, the Slovene enrolment system might be conducive to the emergence of elite general upper secondary schools; however, in this case, the elements of elitism are not exclusively related to private general upper secondary schools. The growth of private education is sustainable, since no private school has terminated its operations. The establishment of private schools has not jeopardised the existence or quality of public schools. It follows that the development of private education has been consistent with the objectives enshrined in the White Paper of 1995. The same conclusion was reached in the analyses included in the White Paper of 2011 (Krek \& Metljak, 2011), which do not recommend any significant changes concerning the regulation of private education.

Another question that now arises is whether the definitions contained in the White Paper have stood the test of time. The answer is provided in the White Paper of 2011, and it is affirmative. Taking human rights as the point of departure cannot be questioned, so the assessment of the guiding principles of the introduction of private education in the White Paper of 1995 is also positive. Since it is now 2021, this appraisal can be amended. In the context in which the White Paper of 1995 was drafted, human rights were synonymous with the withdrawal of the state from the field of education, particularly in the sense 
of protecting the education sphere from political or ideological interventions. When it comes to private education, the White Paper considers human rights primarily in terms of the protection of individuals from state interventions (parents' rights, the right of private schools to exist and operate); meanwhile, the more recent developments in the field of human rights mentioned in the previous section have shifted the focus to the role of the state as the guardian of human rights. Certain provisions from the White Paper of 1995 could nowadays, therefore, be worded differently.

The ruling of the European Court of Human Rights discussed above also indicates the same trend in the understanding of human rights. In the White Paper, the reference to human rights was made in the context of private education primarily to draw attention to the state's responsibility to permit the establishment of private schools and allow parents to choose a type of education; the reference to human rights was less pronounced when addressing the points that the state must regulate private education and set up certain limitations for their operation. Today, what is increasingly in the spotlight is protecting the rights of children and the positive obligation of the state to implement mechanisms for the protection of these rights. From this point of view, it can be said that the objectives of the While Paper have stood the test of time, but that is not entirely the case when it comes to their wording. When assessing the achievement of the objectives of the White Paper, it is worthwhile to examine a process in private education that is so obvious it might just be overlooked.

\section{Normalisation}

One of the benchmarks used for the evaluation of the effectiveness of any regulation in the field of education is its sustainability and stability. Frequent changes give rise to uncertainty, making it impossible for schools to plan for the long term. This is particularly true of fundamental systemic measures such as the regulation of the relationship between private and public schools. ${ }^{5}$ However, stability is related not only to appropriate regulation but also to the acceptance of private schools in society, which is something that can be articulated using the concept of normalisation. This concept was introduced by Stephen Bax to capture the process of the gradual introduction and uptake of new

5 Stable funding which is an important element of the regulation of private education is taken for granted in Slovenia to such an extent that people struggle to understand reports coming from certain Austrian (Becker, 2016) and Croatian (Jarić Dauenhauer, 2016) private schools complaining about unstable and unreliable funding by the state. 
technologies in Computer Assisted Language Learning (CALL). ${ }^{6}$ According to Bax, the normalisation of an innovation is dependant not only on teachers who start using a new technology but also on students, parents, and the broader social environment. Given that the use of a new technology is affected by the characteristics of the novelty, just as much as by the social context, the concept of normalisation can also be applied - with modification and some caution - to the introduction of other innovations in the education system.

Bax (2003, pp. 24-25) considers the adoption of a new technology to be a seven-stage process. Initially, a few enthusiasts will use the novelty while the majority remains sceptical. Then, some people try it out, but most reject it. Positive recommendations lead to new attempts. The novelty is being used, but the public still reacts with fear or exaggerated expectations. By the end of the normalisation process, the novelty has found its place in the education system and it becomes so integrated in the system that everyone uses it without a second thought, and its use does not warrant any special attention.

According to Bax, the initial fear and resistance as well as the advocacy, great expectations, and enthusiasm that mark the individual stages of normalisation are not irrational reactions but rather an integral part of the adoption process of any novelty. If this 'logic of normalisation' is transferred from individuals to society as a whole, it could be said that private education has become largely normalised in Slovenia. Private schools no longer inflame public controversy or motivate letters to the editor, fierce opposition, or tireless advocacy, all of which are integral parts of the normalisation process, according to Bax. Private schools have found their place and become a part of everyday life that is taken for granted and no longer provokes strong reactions.

It should be recalled that the initial years of operation of the Waldorf school were marked by criticism and debates among professionals (e.g., Kosovel, 1997) as well as in letters to the editor (e.g., Divjak, 1995). This was hardly surprising, since schools practising alternative methods were an unknown quantity for the public. In those early days, private schools even reported making adjustments to their curricula in order to bring them closer to those of public schools (Šimenc, 2007). Given that such strong reactions from the public have become a rare occurrence, it could be said that the normalisation period is over. Speaking on behalf of Roman Catholic schools, Roman Globokar

6 Bax chose a rather unfortunate term to designate his concept of a gradual adoption of technological innovation in education. The term 'normalisation' had been used several times before Bax's work to denominate various concepts that are significantly different from Bax's. In the humanities, the most influential concept of normalisation is that of Foucault (Maze, 2020). However, certain authors have a similar understanding of the concept of normalisation as Bax and their theories give normalisation a scope that goes beyond the field of education. The most striking case in point is the normalisation process theory (May \& Finch, 2009). 
(2016) can thus report: 'We have always had an excellent cooperation with public schools; our teachers are members of expert groups for individual subjects and the matura exam at [the] national level, students of various public faculties regularly complete their practical training at our schools' (p. 8). Private schools have become a part of the Slovene education sphere, but that simply cannot be taken for granted. As recently as in 2015 , Globokar's preface (2015) to the journal recalls the situation in which private schools faced misunderstanding and prejudice: 'The publication of the contributions to the symposium seeks to increase the visibility of Catholic schools and overcome the prejudice and misconceptions existing in Slovenia.' (p. 7).

It can be argued that it is the normalisation of private schools that should be considered the greatest achievement of the education reform. Even though it may not be obvious at first sight, the state has made a significant contribution to the acceptance of private schools in society by adopting a regulation that stipulates the conditions schools must fulfil to be officially recognised and eligible for state funding. These 'obstacles' that private schools must overcome can be considered a state guarantee for private schools. Once the curriculum of a private school is officially recognised, after its implementation has been subject to monitoring and once it has been established that it allows students to obtain the required knowledge, a significant milestone is reached. In the eyes of the general public, the new private schools are no longer perceived as a novelty bordering on an experiment but as officially recognised schools with a state guarantee. What may have appeared to be a limitation imposed on private school has turned out to be a condition for their acceptance in society, meaning a condition for their normalisation.?

\section{Conclusion}

The present article presents the regulation of private education adopted as part of the education reform of 1996 and attempts to modify the adopted legislative solutions and goes on to evaluate both the achievement of the goals pursued by the reform as well as the relevance of the principles that guided the reform in the present time. The discussion in the article suggests that the regulation of private education introduced by the education reform in 1996 has stood the test of time. It has done so quite literally, since the solutions that were introduced are largely still valid today even though they were scrutinised by the

7 The politics of polarisation which, according to Galston, are characteristic of the attitude towards education in the USA (Galston, 2005, p. 57) could be mentioned as the opposite of the normalisation logic. What is typical of polarisation in Slovenia is a discourse strategy centred around the notion of a 'state monopoly' over education (e.g., Stres, 2009; Štuhec, 2016). 
Slovenian Parliament and the Constitutional Court. In most countries of Western Europe, there was a period in time when an arrangement of private education established and consolidated itself to such an extent that it is perceived as self-evident today. In this sense, the Slovenian regulation has been a success. It has survived the polarisation phase and has contributed to the normalisation and stability of private education.

The analysis in the article also shows that a trend has emerged in the international arena in the period since the education reform towards interpreting international documents on human rights with greater emphasis on the role of the state in guaranteeing the right to education. The focus is thus no longer on protecting private schools from state intervention, but rather on the positive obligation of the state to implement mechanisms for the protection of the right to education and the rights of students in education. The discussion has also highlighted the 'productive' role of state regulation in the field of private education: as it turns out, the regulatory interventions of the state in the field of education generally impose limitations on private schools, but they can also provide strong support for their normalisation.

\section{References}

Bax, S. (2003). CALL-past, present and future. System, 31(1), 13-28.

Bax, S., \& Chambers, A. (2006). Making CALL work: Towards normalisation. System 34(1), 465-479. Bax, S. (2011). Normalisation revisited: The effective use of technology in language education.

International Journal of Computer-Assisted Language Learning and Teaching, 1(2), 1-15.

Becker, E. (2016, August 2). Privatschulen fordern mehr Geld vom Bund [Private schools demand more money from federal authorities]. DerStandard. https://www.derstandard.at/ story/2000042137119/privatschulen-fordern-mehr-geld-vom-bund Committee on Economic, Social and Cultural Rights. (1999). General Comment 13. The right to education (U.N. Doc. E/C.12/1999/10). United Nations.

Constitutional Court. (2015). (2015). Odločba U-I-269/12-24 [Judgment U-I-269/12-24]. Ustavno sodišče RS. http://www.us-rs.si/media/u-i-269-12.pdf

Divjak, M. (1995, November 18). Štirje razlogi proti waldorfski šoli: waldorfska šola in vzgoja k svobodi [Four reasons against the Waldorf school: the Waldorf school and education for freedom]. Delo.

Dolinar, F. M. (2005). Ljubljanski škofje in zavod sv. Stanislava [The bishops of Ljubljana and Zavod sv. Stanislav]. In F. M. Dolinar (Ed.), Sto let Zavoda sv. Stanislava (pp. 95-124). Družina.

Globokar, R. (2011). Katoliško šolstvo v Sloveniji od1991 do 2011 [Catholic schools in Slovenia from 1991 to 2011]. In M. Šimenc \& V. Tašner (Eds.), Zasebno šolstvo v Sloveniji (pp. 35-61). Pedagoški inštitut. 
Globokar, R. (2015). Uvod [Introduction]. In T. Rifel, R. Globokar \& M. Weilguny (Eds.), Poslanstvo katoliških šol - odgovor na sodobne izzive (p. 7). IREŠ.

Globokar, R. (2016). Zasebno šolstvo kot obogatitev šolskega prostora [Private education as an enrichment of the educational domain]. In T. Rifel \& R. Globokar (Eds.), Zasebno šolstvo za skupno dobro (pp. 7-9). IREŠ.

ECtHR (European Court of Human Rights). (2014a). O'Keeffe O'Keefe v. Ireland: Grand Chamber judgment (Application No. 35810/o9). European Court of Human Rights.

ECtHR (European Court of Human Rights). (2014b). O’Keeffe O’Keefe v. Ireland: Joint partly dissentiing opinion of Judges Zupancic, Gyulumyan, Kalaydjieva, de Gaetano and Woytyczek (Application No. 35810/o9). European Court of Human Rights.

Flere, S., \& Klanjšek, R. (2011). Družbeni izvor staršev v zasebnem in javnem šolstvu [The social origin of parents in private and public education]. In M. Šimenc \& V. Tašner (Eds.), Zasebno šolstvo $v$ Sloveniji (pp. 81-101). Pedagoški inštitut.

Galston, W. A. (2005). The politics of polarization: Education debates in the United States. In S. Fuhrman \& M. Lazerson (Eds.), The public schools (pp. 57-80). Oxford University Press. Jarić Dauenhauer, N. (2016, January 30). Koliko hrvatskih učenika i zašto ide u privatne škole? [How many Croatian students and why go to private schools?]. Tportal.hr. https://www.tportal.hr/vijesti/ clanak/koliko-hrvatskih-ucenika-i-zasto-ide-u-privatne-skole-20160129 Kosovel, I. (1997). Tretja pot - pot gnoze [The third way - the way of gnosis]. Branko. Krek, J. (Ed.). (1996). White paper on education in the Republic of Slovenia. Ministrstvo za šolstvo in šport.

Krek, J., \& Šimenc, M. (Eds.). (1996). Private education. Ministrstvo za šolstvo in šport. Krek, J., \& Metljak, M. (2011). Bela knjiga o vzgoji in izobraževanju v Republiki Sloveniji [White paper on education in the Republic of Slovenia]. Zavod RS za šolstvo in šport. Law. (1996). Zakon o organizaciji in financiranju vzgoje in izobraževanja s komentarjem [Organisation and financing of education act]. Gospodarski vestnik.

Lee, H. (2017). O'Keeffe v. Ireland: The state's obligation to protect children from sexual assault in state schools. Boston College International \& Comparative Law Review, 40(3), 28-40.

Ministry. (2007). Predlog sprememb Zakona o organizaciji in financiranju vzgoje in izobraževanja [Proposed amendments to the organization and financing of education act] (EVA 2007-3311-0004). OECD. (2012). Public and private schools: How management and funding relate to their socio-economic profile. OECD Publishing.

May, C., \& Finch T. (2009). Implementation, embedding, and integration: An outline of normalisation process theory. Sociology, 43(3), 535-554.

Maze, J. (2020). Normativity versus normalisation: reassembling actor-network theory through Butler and Foucault. Culture, Theory and Critique, 61(2), 1-15. https://doi.org./10.1080/14735784.2020 .1780623

Protner, E. (2010). Splošnoizobraževalne zasebne šole na Slovenskem med preteklostjo in sedanjostjo [General education private schools in Slovenia between past and present]. Sodobna pedagogika, 61(5), 
$115-130$.

Protner, E. (2017). Razvoj i aktualno stanje alternativnih pedagoških koncepata u Sloveniji

[Development and current state of alternative pedagogical concepts in Slovenia]. Acta Iadertina, 14(1), 115-130.

Rifel, T. (2016). Napoti ali na poti? [Obstruction or symbiosis]. In T. Rifel \& R. Globokar (Eds.), Zasebno šolstvo za skupno dobro (pp. 24-34). IREŠ.

Sahlberg, P. (2004). Teaching and globalization. Managing Global Transitions, 2(1), 65-83.

Special Rapporteur on the right to education. (2014). Privatization and the right to education

(A/69/402). United Nations.

Special Rapporteur on the right to education. (2015). Report on public-private partnerships and the right to education (A/70/342). United Nations.

Special Rapporteur on the right to education. (2019). Report on Sustainable Development Goal 4 and the growth of private actors in education. United Nations.

Stres, A. (2009, August 12). Nova politika ne ocenjuje pravilno pomena zasebnih šol [The new politics does not properly assess the importance of private schools]. Siolnet. https://siol.net/novice/slovenija/stresnova-politika-ne-ocenjuje-pravilno-pomena-zasebnih-sol-364086

Šimenc, M. (1996). Zasebno šolstvo [Private education]. In J. Krek (Ed.), Zasebno šolstvo: struktura, primerjava različnih šolskih sistemov in zakonodajne rešitve v Republiki Sloveniji (pp. 9-45).

Ministrstvo za šolstvo in šport.

Šimenc, M. (2003). Zasebno šolstvo osem let pozneje [Private education after eight years]. Šolsko polje, 14(5-6), 125-136.

Šimenc, M. (2016). Vpliv odločitev Ustavnega sodišča RS na koncepcijo zasebnega šolstva [The influence of the decisions of the Constitutional Court of the Republic of Slovenia on the conception of private education]. In M. Šimenc \& V. Tašner (Eds.), Komu je napoti kakovostno javno šolstvo? (pp. 47-66). CEPS.

Štuhec, I. (2014). Konceptualni nesporazumi v slovenskem šolskem sistemu [Conceptual misunderstandings in the Slovenian school system]. In T. Rifel \& R. Globokar (Eds.), Zasebno šolstvo za skupno dobro (pp. 35-40). IREŠ.

The Abidjan principles. (2019). https://www.abidjanprinciples.org/

Trnavčevič, A., \& Logaj, V. (2006). Internal marketing and schools: the Slovenian case study.

Managing global transitions, 4(1), 79-96.

Uitz, R. (2014). O'Keeffe v Ireland brings closure to some, uncertainties to others. ECHR blog. https://www.echrblog.com/2014/o2/guest-post-on-grand-chamber-judgment-in.html Verger, A., Fontdevila, C., \& Zancajo, A. (2016). Privatization of Education. Teachers College Press. 


\section{Biographical note}

MARJAN ŠImenc, PhD, is Full professor of philosophy and assistant professor of sociology of education. He works at the Faculty of Education (Ljubljana) and the Faculty of Arts (Ljubljana). He was national research coordinator for CIVED and ICCS (IEA) studies. His main research interests are philosophy and sociology of education. 